\title{
Direct Amide Condensation by Using Supported Boronates
}

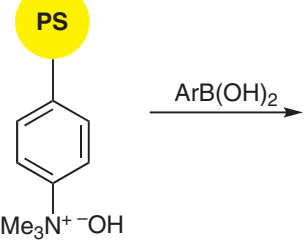

DOWEXTM<smiles></smiles>
1a-c<smiles>Cc1cc([N+](=O)[O-])c([18O])c([N+](=O)[O-])c1</smiles><smiles>Cc1cc(C(F)(F)F)cc(C(F)(F)F)c1</smiles><smiles>Cc1ccccc1Br</smiles><smiles>[R]C(=O)O[Na]</smiles>

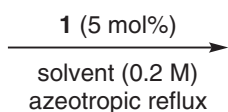
7-19 h<smiles>O=C(CCc1ccccc1)NCc1ccccc1</smiles>

$>99 \%$ NMR yield (1c, PhF, 7 h)<smiles>CCCCCNC(=O)c1ccccc1</smiles>

$>99 \%$ NMR yield (1b, o-xylene, $7 \mathrm{~h}$ )<smiles>[R]C(=O)N([R])[B]</smiles><smiles>CC1CC(C)CN(C(=O)CCc2ccccc2)C1</smiles>

$>99 \%$ NMR yield (1c, PhMe, 19 h)<smiles>O=C(NC(CC(=O)N1CCn2c(nnc2C(F)(F)F)C1)Cc1cc(F)c(F)cc1F)c1ccccc1</smiles>

Significance: Polystyrene resin bound quaternary ammonium boronates 1a-c were prepared by treatment of a commercial anion-exchange resin with the appropriate arylboronic acids (eq. 1). Boronates 1a-c catalyzed the dehydrative condensation of carboxylic acids with amines under azeotropic reflux conditions to give the corresponding amides quantitatively (eq. 2).
Comment: In the dehydrative condensation of 3phenylpropanoic acid with benzylamine, catalyst 1b was recovered by decantation and reused nine times without loss of its catalytic activity. ${ }^{1} \mathrm{H}$ NMR spectroscopy studies suggested that free arylboronic acids were released from the resin into the solution during the reaction. 